\title{
Meta-analysis of the impact of human papillomavirus (HPV) on cancer risk and overall survival in head and neck squamous cell carcinomas (HNSCC)
}

\author{
Farshid Dayyani*1,2, Carol J Etzel³, Mei Liu³, Chung-Han Ho³, Scott M Lippman and Anne S Tsao'
}

\begin{abstract}
Background: HPV is important in a subset of HNSCC. Our meta-analysis determined the clinical characteristics of HPVrelated HNSCC.

Method: Pubmed search terms "HPV" and "HNSCC" were used to identify 34 studies since 1980. We obtained pooled adjusted odds ratio (OR) or hazard ratio (HR) using random or fixed-effects model and compared OS depicted in forest plot.

Results: A total of 5681 patients were included. The prevalence of HPV+ tumors was 22\%, with $86.7 \%$ of HPV $16+$ genotype. The OR for HNSCC in HPV16+ patients was 4.44 (95\% Cl=2.87-6.02). HPV status was associated with p16 expression (adj $\mathrm{OR}=3.00 ; 0.90-9.70$ ), and $\mathrm{HPV}+$ tumors were less likely to harbor p53 mutations (adj $\mathrm{OR}=0.21 ; 0.04$ 0.38). The HR for death in HPV+ patients was 0.42 (0.27-0.57). HPV+ HNSCC also had a better response to therapy.
\end{abstract}

Conclusion: HPV+ HNSCC are established as a separate biologic entity. Prospective trials are needed to establish the optimal therapy for HPV+ HNSCC.

\section{Introduction}

Squamous cell carcinoma of the head and neck (HNSCC) has an estimated incidence of 35,310 new cases in 2008 in the United States, with an expected 7590 deaths due to these cancers. The male to female ratio is approximately 2:1[1]. A recent analysis of the Surveillance, Epidemiology and End Results (SEER) database showed in younger U.S. populations (ages 20-44 years) that while there has been an increase in incidence of tonsillar squamous cell carcinomas from 1973 to 2001, the incidence of squamous cell carcinomas in all other oral and pharyngeal sites remained constant or decreased[2]. A similar rise in the incidence of tonsillar squamous cell carcinomas from 1970-2002 has been shown in Sweden and has been associated with presence of human papillomavirus (HPV)[3]. For more than 30 years, certain genotypes of "high-risk" HPVs have been known to be involved in the pathogene-

* Correspondence: fdayyani@mdanderson.org

${ }^{1}$ Department of Thoracic/Head \& Neck Medical Oncology, University of Texas MD Anderson Cancer Center, Houston, 77030, USA

Full list of author information is available at the end of the article sis of cervical cancers[4]. Recent studies have implicated high-risk HPV as a risk factor for HNSCC, independent of the traditional risk factors, which include tobacco abuse and ethanol consumption[5-7]. While high-risk HPV related HNSCC appear to be associated with certain sexual behaviors, such as oral sex and increasing numbers of sexual partners, there is a lack of association with smoking and drinking[5,8]. Clinically, high-risk-HPV related HNSCC tend to present with lymph node positive disease and originate from the oropharynx, while histologically these tumors are usually high-grade and can be described as exhibiting a basaloid morphology $[6,9,10]$. On a molecular level, the HPV oncoproteins E6 and E7 are implied in tumorigenesis and are known to induce degradation of the tumor suppressors p53 and pRB, respectively[11,12]. Another hallmark of HPV related HNSCC is lack of p53 mutations[13] and p16 protein overexpression[14-16], a result of loss of transcriptional repression which occurs as a response to upstream signals during early tumorigenesis[17]. Studies suggest that 
p16 immunohistochemical expression can function as a surrogate marker to predict treatment outcome in HNSCC $[14,18]$.

Recent emerging data indicates that HPV related HNSCC define a unique population of patients with distinct biology that likely should be treated separately from non-HPV related HNSCC[19]. The aims of this metaanalysis are to consolidate the available data, improve understanding of the biology of HPV related HNSCC, and thereby identify goals for future research and trial design in HNSCC.

\section{Methods}

\section{Article selection}

To identify articles, we searched the Pubmed database, combining permutations of the terms ["human papillomavirus" or "HPV] and ["squamous cell carcinoma" or "cancer"] and ["oropharyngeal" or "oropharynx" or "head and neck" or "tonsil"]. Additional articles from reference lists of retrieved articles were reviewed and included as deemed appropriate. Only articles which solely or separately reported on oropharyngeal cancers, were published from 1980-2008 in English language, and reported HPV prevalence were considered for inclusion. A total of 34 articles met our inclusion criteria for this meta-analysis.

\section{Statistical Analyses}

The presence of study heterogeneity was evaluated using the Chi-squared based $\mathrm{Q}$ test. In order to quantify the extent (estimated as a percent ranging from 0\% to 100\%) of any existing heterogeneity in the meta-analyses, the I2 index was used. Pooled adjusted odds ratios (ORs) for risk or hazard ratios (HRs) for overall survival were obtained using a fixed-effects model (or random-effects model if needed due to among-study heterogeneity). If adjusted ORs or HRs were not available, then we used the same methods as above to pool unadjusted point estimates of risk and survival. Potential sources of publication bias were detected using a funnel plot which is simple scatter plots of the effect of interest versus study size. An asymmetrical funnel plot is indicative of potential publication bias. If necessary, we omitted studies prior to the final meta-analytic estimate that were identified as influential (those outside the allowable bounds based on the presumption of absence of both heterogeneity and publication bias) in the funnel plot. A forest plot was constructed to visually compare all included studies with the final pooled statistic. When possible, we also performed the above meta-analyses for the subset of oropharyngeal cancers. All analyses were completed using STATA 10.0.

\section{Results} HPV Prevalence

A total of 5681 patients in 34 studies were included. To detect HPV DNA in tumor biopsies, 33 studies used PCR, and one study used fluorescence in situ hybridization (FISH). We established a prevalence of HPV among all head and neck squamous cell carcinoma (HNSCC) patients of $21.95 \%$ (95\% CI $=0.21-0.23)$. The most prevalent HPV genotype was HPV-16, representing $86.69 \%$ (95\% CI $=0.85-0.89)$ of all HPV positive tumors (Table 1 and 2). The other two most commonly detected genotypes were HPV-18 and -33 (data not shown). In the publications which included information on the subgroup of oropharyngeal cancers, the prevalence of HPV was $41 \%$ (379 of 925 patients; $95 \% \mathrm{CI}=0.38-0.44$ ).

\section{HPV as Risk Factor for HNSCC}

Overall, positive HPV status (any high-risk genotype) conferred an increased risk for HNSCC (adjusted OR = $1.83 ; 95 \% \mathrm{CI}=1.04-2.62 ; \mathrm{p}<0.0001$ ) as seen in Figure $1 \mathrm{~A}$. Risk for HNSCC among HPV-16 positive patients was 4.44 times $(95 \% \mathrm{CI}=2.87-6.02$; $\mathrm{p}<0.0001)$ that of HPV16 negative patients (Figure $1 \mathrm{~B}$ ). As a validation control for our meta-analysis we assessed the OR of two known risk factors for HNSCC, tobacco and alcohol consumption[20,21]. We confirmed that heavy smokers and alcohol drinkers are at increased risk for HNSCC (smoking $\mathrm{OR}=3.53 ; 95 \% \mathrm{CI}=2.69-4.64, \mathrm{p}<0.0001$, and alcohol consumption $\mathrm{OR}=4.04 ; 95 \% \mathrm{CI}=3.20-5.09, \mathrm{p}<0.0001$ ). Table 3 shows the association of HPV status with prognostic factors for HNSCC (age, gender, and tumor stage) and known risk factors for HNSCC (ethanol and tobacco consumption)

\section{HPV and Survival}

Survival was improved in HPV positive patients compared to $\mathrm{HPV}$ negative patients $(\mathrm{HR}=0.42 ; 95 \% \mathrm{CI}=$ $0.27-0.56, \mathrm{p}<0.0001$ ) (Figure 2A). The survival benefit was similar in HPV-16 positive patients (adjusted $\mathrm{HR}=$ $0.41 ; 95 \% \mathrm{CI}=0.21-0.61, \mathrm{p}<0.0001)$. The improved survival in HPV positive patients was even more pronounced in the subgroup of oropharyngeal cancers (adjusted HR $=0.40 ; \mathrm{CI}=0.18-0.61, \mathrm{p}<0.0001$ ) (Figure 2B).

\section{HPV and Treatment Response}

A total of ten publications included treatment information, but only two reported statistical information on treatment response to radiotherapy and two reported efficacy results to chemotherapy/radiotherapy (Table 4). HPV positive HNSCC have a better response to radiotherapy compared to HPV negative HNSCC (non- 
Table 1: HPV Prevalence in 34 trials $(N=5681)$

\begin{tabular}{|c|c|c|c|c|c|}
\hline Title & Patients (n) & $\begin{array}{l}\text { No. of HPV } \\
\text { positive (n) }\end{array}$ & $\begin{array}{c}\text { Prevalence } \\
\text { HPV \% }\end{array}$ & $\begin{array}{c}\text { No. of } \\
\text { HPV16 (n) }\end{array}$ & $\begin{array}{c}\text { Prevalence HPV16 in } \\
\text { HPV (\%) }\end{array}$ \\
\hline Mork rtl, et al. 2001 & 292 & 88 & $30.14 \%$ & 35 & $39.77 \%$ \\
\hline D'Souza, et al. 2007 & 100 & 40 & $40.00 \%$ & 35 & $87.50 \%$ \\
\hline Gillison, et al. 2000 & 253 & 62 & $24.51 \%$ & 56 & $90.32 \%$ \\
\hline Herrero, et al. 2003 & 1670 & 56 & $3.35 \%$ & 21 & $37.50 \%$ \\
\hline Smith, et al. 2004 & 201 & 46 & $22.89 \%$ & 39 & $84.78 \%$ \\
\hline Braakhuis, et al. 2004 & 143 & 24 & $16.78 \%$ & 24 & $100.00 \%$ \\
\hline Fakhry, et al. 2008 & 96 & 38 & $39.58 \%$ & 36 & $94.74 \%$ \\
\hline Teman, et al. 2008 & 105 & 12 & $11.43 \%$ & 0 & $0.00 \%$ \\
\hline Weinberger, et al. 2006 & 77 & 47 & $61.04 \%$ & 47 & $100.00 \%$ \\
\hline Licitra, et al. 2006 & 90 & 17 & $18.89 \%$ & 17 & $100.00 \%$ \\
\hline Worden, et al. 2008 & 66 & 27 & $40.91 \%$ & 27 & $100.00 \%$ \\
\hline Shindoh, et al. 1995 & 77 & 24 & $31.17 \%$ & 24 & $100.00 \%$ \\
\hline Lindel, et al. 2001 & 99 & 14 & $14.14 \%$ & 11 & $78.57 \%$ \\
\hline Klussmann, et al. 2001 & 98 & 25 & $25.51 \%$ & 21 & $84.00 \%$ \\
\hline Perrone, et al. 2007 & 77 & 16 & $20.78 \%$ & 16 & $100.00 \%$ \\
\hline Kutler, et al. 2003 & 25 & 21 & $84.00 \%$ & 19 & $90.48 \%$ \\
\hline Smith, et al. 2004 & 193 & 38 & $19.69 \%$ & 33 & $86.84 \%$ \\
\hline Baez, et al. 2004 & 118 & 52 & $44.07 \%$ & 52 & $100.00 \%$ \\
\hline Dahlgren, et al. 2004 & 110 & 12 & $10.91 \%$ & 9 & $75.00 \%$ \\
\hline Hoffmann, et al. 2004 & 73 & 28 & $38.36 \%$ & 28 & $100.00 \%$ \\
\hline Slebos, et al. 2006 & 36 & 8 & $22.22 \%$ & 8 & $100.00 \%$ \\
\hline Hammarstedt, et al. 2006 & 203 & 99 & $48.77 \%$ & 86 & $86.87 \%$ \\
\hline Ragin, et al. 2006 & 125 & 30 & $24.00 \%$ & 30 & $100.00 \%$ \\
\hline Reimers, et al. 2007 & 106 & 30 & $28.30 \%$ & 29 & $96.67 \%$ \\
\hline Furniss, et al. 2007 & 486 & 145 & $29.84 \%$ & 145 & $100.00 \%$ \\
\hline Smith, et al. 2008 & 301 & 81 & $26.91 \%$ & 77 & $95.06 \%$ \\
\hline Pintos, et al. 2008 & 72 & 14 & $19.44 \%$ & 13 & $92.86 \%$ \\
\hline Charfi, et al. 2008 & 52 & 32 & $61.54 \%$ & 27 & $84.38 \%$ \\
\hline Westra, et al. 2008 & 89 & 12 & $13.48 \%$ & 12 & $100.00 \%$ \\
\hline Hafkamp, et al. 2008 & 81 & 33 & $40.74 \%$ & 33 & $100.00 \%$ \\
\hline Friesland, et al. 2001 & 34 & 14 & $41.18 \%$ & 14 & $100.00 \%$ \\
\hline De Petrini, et al. 2006 & 47 & 20 & $42.55 \%$ & 20 & $100.00 \%$ \\
\hline Wittekindt, et al. 2005 & 34 & 18 & $52.94 \%$ & 16 & $88.89 \%$ \\
\hline \multirow[t]{2}{*}{ Strome, et al. 2002} & 52 & 24 & $46.15 \%$ & 21 & $87.50 \%$ \\
\hline & 5681 & 1247 & $21.95 \%$ & 1081 & $86.69 \%$ \\
\hline
\end{tabular}

adjusted $\mathrm{OR}=4.07 ; 95 \% \mathrm{CI}=1.48-11.18, \mathrm{p}=0.006)$. Similarly, patients who are positive for HPV have an improved response to concurrent chemo-radiation (nonadjusted $\mathrm{OR}=2.87 ; 95 \% \mathrm{CI}=1.29-6.41, \mathrm{p}=0.01$ ).

\section{Correlation with p16 and p53}

Several studies reported p16 immunohistochemical expression in HPV positive HNSCC[22-29]. We found that HPV status was associated with p16 expression (adjusted OR $=3.00 ; 95 \% \mathrm{CI}=0.90-9.70, \mathrm{p}=0.18$ ), and HPV positive tumors were less likely to harbor p53 mutations (adjusted OR $=0.21 ; 95 \% \mathrm{CI}=0.04-0.38, \mathrm{p}=0.015$ ) (Table 5). Confirming the notion that p16 expression might be used as a surrogate for HPV status in HNSCC, we show that p16 positive HNSCC have reduced hazard 
Table 2: Selected characteristics of the 34 studies

\begin{tabular}{|c|c|c|c|}
\hline & & $\mathbf{N}$ & $\%$ \\
\hline \multirow[t]{4}{*}{ Confounding factors } & Age & 22 & $64.71 \%$ \\
\hline & Gender & 24 & $70.59 \%$ \\
\hline & Smoking & 15 & $44.12 \%$ \\
\hline & Alcohol & 15 & $44.12 \%$ \\
\hline \multirow[t]{6}{*}{ Study type } & Case-control & 6 & $17.65 \%$ \\
\hline & Nested Case Control & 1 & $2.94 \%$ \\
\hline & Multi-Center Case Control & 1 & $2.94 \%$ \\
\hline & Case Series & 3 & $8.82 \%$ \\
\hline & Retrospective & 20 & $58.82 \%$ \\
\hline & Prospective & 3 & $8.82 \%$ \\
\hline Sample size & $<50$ & 5 & $14.71 \%$ \\
\hline \multirow[t]{3}{*}{ (No. of patients) } & $50-99$ & 14 & $41.18 \%$ \\
\hline & $100-149$ & 7 & $20.59 \%$ \\
\hline & $>150$ & 8 & $23.53 \%$ \\
\hline \multirow[t]{4}{*}{ Prevalence HPV } & $<25 \%$ & 14 & $41.18 \%$ \\
\hline & $25 \%-50 \%$ & 14 & $41.18 \%$ \\
\hline & $50 \%-75 \%$ & 5 & $14.71 \%$ \\
\hline & $>75 \%$ & 1 & $2.94 \%$ \\
\hline \multirow[t]{4}{*}{ Prevalence HPV-16 } & $<25 \%$ & 16 & $47.06 \%$ \\
\hline & $25 \%-50 \%$ & 13 & $38.24 \%$ \\
\hline & $50 \%-75 \%$ & 4 & $11.76 \%$ \\
\hline & $>75 \%$ & 1 & $2.94 \%$ \\
\hline \multirow[t]{2}{*}{ Method of Detection } & PCR & 33 & $97.06 \%$ \\
\hline & FISH & 1 & $2.94 \%$ \\
\hline \multirow[t]{12}{*}{ Country } & USA & 14 & $41.18 \%$ \\
\hline & Canada & 1 & $2.94 \%$ \\
\hline & Puerto Rico & 1 & $2.94 \%$ \\
\hline & France & 2 & $5.88 \%$ \\
\hline & Germany & 4 & $11.76 \%$ \\
\hline & Netherlands & 2 & $5.88 \%$ \\
\hline & Italy & 3 & $8.82 \%$ \\
\hline & Switzerland & 1 & $2.94 \%$ \\
\hline & Norway, Finland, Sweden & 1 & $2.94 \%$ \\
\hline & Sweden & 3 & $8.82 \%$ \\
\hline & Japan & 1 & $2.94 \%$ \\
\hline & International & 1 & $2.94 \%$ \\
\hline
\end{tabular}


A

Study

$\%$

ID

ES $(95 \% \mathrm{Cl}) \quad$ Weight

\begin{tabular}{lll} 
Smith, et al. 2004 & $1.80(1.10,2.70) \quad 97.50$ \\
Pintos, et al. 2008 & $3.14(0.90,10.90) 2.50$ \\
Noverall (I-squared $=0.0 \%, p=0.604)$ & $1.83(1.04,2.62) \quad 100.00$ \\
\hline-10.9 & 1 & 10.9
\end{tabular}

B

Study

$\%$

ID

ES $(95 \% \mathrm{Cl}) \quad$ Weight

Furniss, et al. 2007
Pintos, et al. 2008
Overall (l-squared $=0.0 \%, p=0.761)$
Note: Wueights are trom random effects analysis

Figure 1 Meta-analyses for adjusted odds ratio (OR) for HPV as risk factor for HNSCC Risk for having HNSCC is increased with all types of high-risk HPV reported (A) and risk is even more pronounced in cases with HPV-16 infection versus HPV negative controls (B). 
Table 3: Association of HPV status with gender, age, tumor stage, alcohol and tobacco consumption

\begin{tabular}{|c|c|c|c|c|c|}
\hline Demographic & \# Studies & HPV status & Smoking status & $\mathbf{N}$ & $\%$ \\
\hline \multirow[t]{4}{*}{ Tobacco } & 17 & $\mathrm{HPV}+$ & Ever & 1068 & 55.9 \\
\hline & & & Never & 948 & 44.1 \\
\hline & & HPV- & Ever & 2179 & 74.5 \\
\hline & & & Never & 677 & 25.5 \\
\hline \multirow[t]{4}{*}{ Ethanol } & 16 & HPV+ & Ever & 1548 & 66.8 \\
\hline & & & Never & 768 & 33.2 \\
\hline & & HPV- & Ever & 2186 & 75.4 \\
\hline & & & Never & 713 & 24.6 \\
\hline \multirow[t]{4}{*}{ Stage } & $10^{*}$ & $\mathrm{HPV}+$ & $I-I I$ & 78 & 26.7 \\
\hline & & & III-IV & 214 & 73.3 \\
\hline & & HPV- & I-II & 259 & 42.8 \\
\hline & & & III-IV & 346 & 57.2 \\
\hline \multirow[t]{4}{*}{ LN Stage } & 6 & $\mathrm{HPV}+$ & No & 45 & 33.5 \\
\hline & & & N1-N3 & 123 & 66.5 \\
\hline & & HPV- & No & 204 & 45.9 \\
\hline & & & N1-N3 & 240 & 54.1 \\
\hline \multirow[t]{4}{*}{ Gender } & 18 & $\mathrm{HPV}+$ & M & 1525 & 67.8 \\
\hline & & & $\mathrm{F}$ & 724 & 32.2 \\
\hline & & HPV- & $M$ & 2010 & 66.1 \\
\hline & & & $\mathrm{F}$ & 1033 & 33.9 \\
\hline \multirow[t]{2}{*}{ Median Age } & $5^{* *}$ & $\mathrm{HPV}+$ & 55 years & & \\
\hline & & HPV- & 60 years & & \\
\hline
\end{tabular}

HPV: human papillomavirus; M: male; F: female; LN, lymph node; * 2 studies compared stage I-III vs. stage IV; ** 5 studies reported the median age of the subjects.

ratio for death (adjusted $\mathrm{HR}=0.22 ; 95 \% \mathrm{CI}=0.02-0.41, \mathrm{p}$ $=0.028)$.

\section{Discussion}

We have conducted a literature review and large metaanalysis in HPV related HNSCC to determine the prevalence of the disease and assess the ramifications on survival and associated molecular biomarkers. Given prior published reports of a higher prevalence of HPV in carcinomas of the oropharynx, we concentrated this study on oropharyngeal carcinomas to enrich and focus the metaanalysis. Therefore, the number of studies included in our review is smaller than other previously reported metaanalyses with different inclusion criteria[30,31]. Several other meta-analyses on HPV-related HNSCC have been published before[30-32], but to our knowledge, none of the prior reports have described within the same report, the impact of HPV on survival, response to therapy, as well as the association with molecular markers such as p16. In addition, our report includes recently published prospective studies that were not available at the time of publication of previous meta-analyses. Our data reports the prevalence of HPV-related HNSCC as $21.95 \%$ and is in accordance with other recently published reports which estimate the prevalence of HPV at 20-26\% [25,3032]. As expected, we also confirmed a higher prevalence of HPV-related tumors in the oropharynx (40.97\%) in agreement with prior studies[31,33]. Virtually all of the studies included used PCR to detect HPV DNA, a method with slightly higher sensitivity than in situ hybridization[31]. The higher sensitivity of the detection method used suggests that the herein reported prevalence of HPV associated HNSCC is more likely to reflect the actual prevalence of HPV as compared to studies which use less sensitive methods, although given the paucity of data regarding the exact specificity of PCR in this setting does not enable a precise account of the number of false-positive patients included in these studies. The relatively wide range of the prevalence of HPV in HNSCC in the published literature confirms that in addition to 
A

Study

ID

ES $(95 \%$ Cl) Weight

Gillison, et al. 2000

Fakhry, et al. 2008

Lindel, et al. 2001

Reimers, et al. 2007

Smith, et al. 2008

Hafkamp, et al. 2008

Strome, et al. 2002

Overall (l-squared $=0.0 \%, p=0.914$ )

NOTE: Weights are from random effects analysis

B

Study

ID
$\%$

ES $(95 \% \mathrm{Cl}) \quad$ Weight
Fakhry, et al. 2008

Lindel, et al. 2001

Reimers, et al. 2007

Hafkamp, et al. 2008

Strome, et al. 2002

Overall (l-squared $=0.0 \%, p=0.989$ )

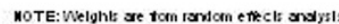

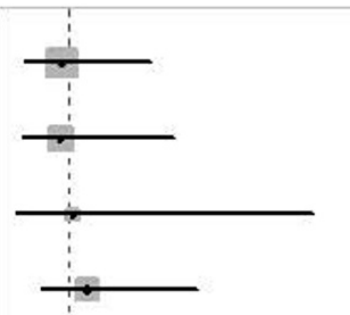

$0.36(0.15,0.85) \quad 38.00$

$0.35(0.13,0.98) \quad 25.77$

$0.42(0.10,1.76) \quad 6.76$

$0.50(0.24,1.11) \quad 24.43$

$0.40(0.08,2.00) \quad 5.05$

$0.40(0.18,0.61) \quad 100.00$

Figure 2 Overall survival of HPV positive patients compared to HPV negative patients in unselected HNSCC patients (A) and in the subgroup of patients with oropharyngeal cancers (B). 
Table 4: Treatment type and country of origin of studies that reported treatment information

\begin{tabular}{lll}
\hline Author, Year & Type of Treatment & Country \\
\hline Fakhry, et al. 2008 & CTX followed by Chemo-XRT & United States \\
Weinberger, et al. 2006 & XRT \pm surgery & United States \\
Worden, et al. 2008 & CTX followed by Chemo-XRT or XRT/surgery & United States \\
Lindel, et al. 2001 & XRT & Switzerland \\
Dahlgren, et al. 2004 & XRT & Sweden \\
Smith, et al. 2008 & XRT \pm surgery & United States \\
Hafkamp, et al. 2008 & CTX \pm XRT \pm surgery & Netherlands \\
Friesland, et al. 2001 & XRT & Sweden \\
\hline
\end{tabular}

CTX: Chemotherapy; XRT: Radiotherapy; Chemo-XRT: concurrent chemo-radiation

geographical differences, the method of HPV detection is critical for accurate assessment of the HPV status.

In the current study we confirmed the role of p16 immunohistochemical expression as a surrogate marker for HPV infection in HNSCC, which is not only positively associated with HPV infection but also predicts for an improved survival outcome[14,28,29]. The HPV oncoprotein E7 is known to induce degradation of $\mathrm{pRb}$, which in turn leads to upregulation of p16[34]. Therefore, overexpression of $\mathrm{p} 16$ is considered to be one of the molecular hallmarks of HPV positive HNSCC $[4,23,35,36]$ and has recently been shown to identify HPV related oropharyngeal cancers with favorable outcomes[16]. In a recent prospective trial, an analysis of tumor tissue $(n=323)$ collected from RTOG 0129 using HPV in situ hybridization (ISH) and p16 immunohistochemistry (IHC) demonstrated that p16 correlated well with HPV ISH with 96\% of HPV positive tumors also expressing p16[19]. An additional 19\% $(\mathrm{n}=22)$ were $\mathrm{p} 16$ positive but HPV negative. Both HPV and p16 positive status predicted for an improved survival. This finding of p16 IHC positive tumors identifying more patients than HPV ISH was also seen in an additional study called HeadStart[37]. This trial compared HPV ISH and p16 IHC on tumor specimens from two arms of therapy, cisplatin-radiation versus cisplatin-tirapazamine-radiation, and suggested that p16 IHC may identify a higher percentage of HPV positive tumors than the HPV ISH assay. Given the debate regarding the best detection method for HPV [38], our data from the meta-analysis confirms that p16 IHC could be used in future in prospective trials as a reliable surrogate marker for HPV related HNSCC[19,37,39]. As the above two recent studies (RTOG and HeadStart) have only been reported in abstract form, we did not include them in our meta-analysis.

As HPV-related oropharyngeal cancers are reported to be rising in incidence[2,3], it is important to consider treating this disease as a unique entity. Our data in congruence with other studies indicate that HPV positive HNSCC have a distinct biology, and are more responsive to treatment with radiotherapy and chemotherapy. In addition to treatment response, we and others have shown an improved survival in patients with HPV positive HNSCC, with a $60 \%$ lower risk of death. Our survival results are slightly different from other reports; a recent meta-analysis reported a death hazard ratio of 0.85 . This discrepancy can be explained by the addition of the recent prospective trials $[10,14,40,41]$ in our analysis which were not included in prior reports. Our meta-analysis also confirms a better response to treatment in HPV

Table 5: Meta-analyses of association between p53 mutations, p16 and HPV

\begin{tabular}{|c|c|c|c|c|c|}
\hline \multirow[b]{2}{*}{ Outcome } & \multirow[b]{2}{*}{ Marker } & \multicolumn{2}{|c|}{ Before outlier exclusion } & \multicolumn{2}{|c|}{ After outlier exclusion } \\
\hline & & No. of Studies & $\begin{array}{l}\text { Adjusted OR (95\% } \\
\text { Cl) }\end{array}$ & No. of Studies & $\begin{array}{c}\text { Adjusted OR (95\% } \\
\mathrm{Cl})\end{array}$ \\
\hline \multirow[t]{2}{*}{ HPV positive } & p53 (mutated) & 4 & $0.21(0.04-0.38)$ & 4 & $0.21(0.04-0.38)$ \\
\hline & & & & & $P=0.015$ \\
\hline \multirow[t]{2}{*}{ HPV positive } & p16 & 2 & $5.02(1.08-8.97)$ & 1 & $3.00(0.90-9.70)$ \\
\hline & $\mathrm{IHC}$ & & & & $p=0.181$ \\
\hline
\end{tabular}


positive HNSCC in accordance with recently published trials[10,14,39,41,42]. Recent reports have highlighted the importance of the negative influence of smoking on prognosis within HPV positive HNSCC [19,43], and future studies are required to examine this relationship in a prospective manner.

There are several limitations inherent to our methodology, which was based on literature review, not individual patient data. While the total number of patients included in our meta-analysis is large, for many specific associations the number of the studies that actually could be combined to provide information is relatively small. This is a limitation which unfortunately cannot be overcome without access to primary data from all included publications. Also, there is overlap of the same patient series included in multiple reports. We tried to account for this fact as much as possible by reviewing the author list and institution of each paper and including only the largest study if several were apparently from the same group. Finally, given the heterogeneity of the kinds of studies our meta-analysis was based on, it is difficult to combine conclusions drawn, e.g. assessing HPV as risk factor for HNSCC from case series, retrospective and prospective trials. There is no valid formulation to give adequate weight to the results of each kind of the studies mentioned. In spite of the limitations inherent to this type of a meta-analysis, our results are in keeping with published literature and our current understanding of the natural biology of HPV-related HNSCC. We also performed as a validation control a meta-analysis for the established HNSCC risk factors smoking and alcohol consumption. Our results confirmed prior published results [20,21].

For the future, there is a need for randomized prospective data to identify the optimal treatment for patients based on the tumor's HPV status and to also develop potential prevention programs. First, given the apparent improved response to current treatment modalities, patients with HPV-related HNSCC may be able to receive adequate curative intent therapy from a reduction in radiation or chemotherapy dose. These issues will require future clinical trial designs to either prospectively stratify patients by HPV status or to conduct trials which are dedicated to HPV positive HNSCC. In addition, it is necessary to determine the best method of detecting the HPV status and validate whether p16 overexpression should be utilized as a surrogate or in conjunction with direct HPV testing. Given the etiologic involvement of the HPV oncoproteins E6 and E7 during carcinogenesis of these tumors[44], it is also conceivable that intervention with anti-viral drugs may enhance sensitivity of these tumors to cytotoxic drugs, with the goal of reducing the required dose of chemotherapeutic agents and the associated side effects. Exploratory biomarker studies will be needed to identify prognostic and predictive markers in order to tailor specific therapies (such as biologic agents) to the biology of the patients' malignancy, resulting in better tolerability of treatment with improved outcomes.

The issue of preventing HPV associated HNSCC from occurring requires investigation as well. Two recently approved vaccines to prevent HPV-related cervical cancers $[45,46]$ cover the two serotypes that are most prevalent in HPV-related HNSCC (HPV-16 and 18). In the context of the findings of our study, it is conceivable that extending vaccination to both sexes would prevent a significant number of future oropharyngeal cancers in both men and women. Also, the hypothesized benefits of HPV-vaccination would potentially include a reduced incidence of other HPV-related cancers (i.e. vulvar, vaginal, anal, and penile cancers)[47]. On the other hand, a recent study showed that vaccination of males on a population basis might not be cost-effective[48]. Even in women, controversy exists regarding the maximum age at which the HPV-vaccine should be given, and a recent simulation model suggested that vaccination beyond 30 years of age might also not be cost-effective[49]. Given all these uncertainties, it will therefore be of great importance to assess in prospective trials that include both sexes the efficacy of these vaccines to prevent HPVrelated $\mathrm{HNSCC}$.

\section{Conclusions}

HPV-related HNSCC comprise about 25\% of all HNSCC. They are predominantly tumors of the oropharynx, and exhibit a separate biologic behavior including improved response to (chemo)-radiation and survival compared to HPV-negative HNSCC. The optimal therapy for this subset of patients remains unclear, but the growing data supports the theory that this subset of patients should be treated differently than HPV negative patients. In addition to this avenue of clinical research, identifying peripheral surrogate biomarkers and possible screening and prevention methods is an important field of future investigation.

\section{Declaration of Competing Interests}

The authors declare that they have no competing interests.

\section{Authors' contributions}

FD and AST designed the study, acquired and interpreted the data, and wrote the manuscript. CJE, ML, and CHH acquired, analyzed, and interpreted the data, and contributed to manuscript writing. SML contributed to study design, data interpretation and manuscript writing. All authors have given final approval of the version to be published.

\section{Author Details}

'Department of Thoracic/Head \& Neck Medical Oncology, University of Texas MD Anderson Cancer Center, Houston, 77030, USA, ${ }^{2}$ Division of Cancer

Medicine, University of Texas MD Anderson Cancer Center, Houston, 77030, USA and ${ }^{3}$ Department of Epidemiology, University of Texas MD Anderson Cancer Center, Houston, 77030, USA 
Received: 15 June 2010 Accepted: 29 June 2010

Published: 29 June 2010

\section{References}

1. Jemal A, Siegel R, Ward E, Hao Y, Xu J, Murray T, Thun MJ: Cancer statistics, 2008. CA: a cancer journal for clinicians 2008, 58(2):71-96.

2. Shiboski CH, Schmidt BL, Jordan RC: Tongue and tonsil carcinoma: increasing trends in the U.S. population ages 20-44 years. Cancer 2005, 103(9):1843-1849.

3. Hammarstedt L, Lindquist $\mathrm{D}$, Dahlstrand $\mathrm{H}$, Romanitan $\mathrm{M}$, Dahlgren $\mathrm{LO}$, Joneberg J, Creson N, Lindholm J, Ye W, Dalianis T, et al:: Human papillomavirus as a risk factor for the increase in incidence of tonsillar cancer. International journal of cancer 2006, 119(11):2620-2623.

4. zur Hausen H: Papillomaviruses and cancer: from basic studies to clinical application. Nature reviews 2002, 2(5):342-350.

5. D'Souza G, Kreimer AR, Viscidi R, Pawlita M, Fakhry C, Koch WM, Westra WH, Gillison ML: Case-control study of human papillomavirus and oropharyngeal cancer. The New England journal of medicine 2007, 356(19):1944-1956.

6. Gillison ML, Koch WM, Capone RB, Spafford M, Westra WH, Wu L, Zahurak ML, Daniel RW, Viglione M, Symer DE, et al.: Evidence for a causal association between human papillomavirus and a subset of head and neck cancers. Journal of the National Cancer Institute 2000, 92(9):709-720

7. Gillison ML, Shah KV: Human papillomavirus-associated head and neck squamous cell carcinoma: mounting evidence for an etiologic role for human papillomavirus in a subset of head and neck cancers. Current opinion in oncology 2001, 13(3):183-188.

8. Gillison ML, D'Souza G, Westra W, Sugar E, Xiao W, Begum S, Viscidi R: Distinct risk factor profiles for human papillomavirus type 16-positive and human papillomavirus type 16-negative head and neck cancers. Journal of the National Cancer Institute 2008, 100(6):407-420.

9. Andl T, Kahn T, Pfuhl A, Nicola T, Erber R, Conradt C, Klein W, Helbig M, Dietz A, Weidauer $H$, et al.: Etiological involvement of oncogenic human papillomavirus in tonsillar squamous cell carcinomas lacking retinoblastoma cell cycle control. Cancer research 1998, 58(1):5-13.

10. Fakhry C, Westra WH, Li S, Cmelak A, Ridge JA, Pinto H, Forastiere A, Gillison ML: Improved survival of patients with human papillomaviruspositive head and neck squamous cell carcinoma in a prospective clinical trial. Journal of the National Cancer Institute 2008, 100(4):261-269.

11. Dyson N, Howley PM, Munger K, Harlow E: The human papilloma virus$16 \mathrm{E} 7$ oncoprotein is able to bind to the retinoblastoma gene product. Science (New York, NY) 1989, 243(4893):934-937.

12. Werness BA, Levine AJ, Howley PM: Association of human papillomavirus types 16 and $18 \mathrm{E} 6$ proteins with p53. Science (New York, NY) 1990, 248(4951):76-79.

13. Westra WH, Taube JM, Poeta ML, Begum S, Sidransky D, Koch WM: Inverse relationship between human papillomavirus-16 infection and disruptive p53 gene mutations in squamous cell carcinoma of the head and neck. Clin Cancer Res 2008, 14(2):366-369.

14. Kumar B, Cordell KG, Lee JS, Worden FP, Prince ME, Tran HH, Wolf GT, Urba SG, Chepeha DB, Teknos TN, et al.: EGFR, p16, HPV Titer, Bcl-xL and p53, sex, and smoking as indicators of response to therapy and survival in oropharyngeal cancer. J Clin Oncol 2008, 26(19):3128-3137.

15. O'Regan EM, Toner ME, Finn SP, Fan CY, Ring M, Hagmar B, Timon C, Smyth P, Cahill S, Flavin R, et al:: p16(INK4A) genetic and epigenetic profiles differ in relation to age and site in head and neck squamous cell carcinomas. Human pathology 2008, 39(3):452-458.

16. Weinberger PM, Yu Z, Haffty BG, Kowalski D, Harigopal M, Brandsma J, Sasaki C, Joe J, Camp RL, Rimm DL, et al:: Molecular classification identifies a subset of human papillomavirus--associated oropharyngeal cancers with favorable prognosis. J Clin Oncol 2006, 24(5):736-747

17. Mroz EA, Baird AH, Michaud WA, Rocco JW: $\mathrm{COOH}$-terminal binding protein regulates expression of the p16INK4A tumor suppressor and senescence in primary human cells. Cancer research 2008, 68(15):6049-6053.

18. Nichols AC, Faquin WC, Westra WH, Mroz EA, Begum S, Clark JR, Rocco JW: HPV-16 infection predicts treatment outcome in oropharyngeal squamous cell carcinoma. Otolaryngol Head Neck Surg 2009, 140(2):228-234
19. Gillison HJ ML, Westra W, Chung C, Jordan R, Rosenthal D, Nguyen-Tan P, Spanos WJ, Redmond KP, Ang K: Survival outcomes by tumor human papillomavirus (HPV) status in stage III-IV oropharyngeal cancer (OPC) in RTOG 0129. J Clin Oncol 2009, 27:15s.

20. Murata M, Takayama K, Choi BC, Pak AW: A nested case-control study on alcohol drinking, tobacco smoking, and cancer. Cancer detection and prevention 1996, 20(6):557-565.

21. Spitz MR: Epidemiology and risk factors for head and neck cancer. Seminars in oncology 1994, 21(3):281-288.

22. Charfi L, Jouffroy T, de Cremoux P, Le Peltier N, Thioux M, Freneaux P, Point D, Girod A, Rodriguez J, Sastre-Garau X: Two types of squamous cell carcinoma of the palatine tonsil characterized by distinct etiology, molecular features and outcome. Cancer letters 2008, 260(1-2):72-78,

23. Hafkamp HC, Manni JJ, Haesevoets A, Voogd AC, Schepers M, Bot FJ, Hopman AH, Ramaekers FC, Speel EJ: Marked differences in survival rate between smokers and nonsmokers with HPV 16-associated tonsillar carcinomas. International journal of cancer 2008, 122(12):2656-2664.

24. Licitra L, Perrone F, Bossi P, Suardi S, Mariani L, Artusi R, Oggionni M, Rossini C, Cantu G, Squadrelli M, et al:: High-risk human papillomavirus affects prognosis in patients with surgically treated oropharyngeal squamous cell carcinoma. J Clin Oncol 2006, 24(36):5630-5636.

25. Ragin CC, Taioli E, Weissfeld JL, White JS, Rossie KM, Modugno F, Gollin SM: 11 13 amplification status and human papillomavirus in relation to p16 expression defines two distinct etiologies of head and neck tumours. British journal of cancer 2006, 95(10):1432-1438.

26. Reimers N, Kasper HU, Weissenborn SJ, Stutzer H, Preuss SF, Hoffmann TK, Speel EJ, Dienes HP, Pfister HJ, Guntinas-Lichius O, et al.: Combined analysis of HPV-DNA, p16 and EGFR expression to predict prognosis in oropharyngeal cancer. International journal of cancer 2007 120(8): $1731-1738$

27. Slebos RJ, Yi Y, Ely K, Carter J, Evjen A, Zhang X, Shyr Y, Murphy BM, Cmelak AJ, Burkey BB, et al: Gene expression differences associated with human papillomavirus status in head and neck squamous cell carcinoma. Clin Cancer Res 2006, 12(3 Pt 1):701-709.

28. Smith EM, Wang D, Kim Y, Rubenstein LM, Lee JH, Haugen TH, Turek LP: P16INK4a expression, human papillomavirus, and survival in head and neck cancer. Oral oncology 2008, 44(2):133-142.

29. Wittekindt C, Gultekin E, Weissenborn SJ, Dienes HP, Pfister HJ, Klussmann $J P$ : Expression of $\mathrm{p} 16$ protein is associated with human papillomavirus status in tonsillar carcinomas and has implications on survival. Advances in oto-rhino-laryngology 2005, 62:72-80.

30. Kreimer AR, Clifford GM, Boyle P, Franceschi S: Human papillomavirus types in head and neck squamous cell carcinomas worldwide: a systematic review. Cancer Epidemiol Biomarkers Prev 2005, 14(2):467-475.

31. Termine N, Panzarella V, Falaschini S, Russo A, Matranga D, Lo Muzio L, Campisi G: HPV in oral squamous cell carcinoma vs head and neck squamous cell carcinoma biopsies: a meta-analysis (1988-2007). Ann Oncol 2008, 19(10):1681-1690.

32. Ragin CC, Taioli E: Survival of squamous cell carcinoma of the head and neck in relation to human papillomavirus infection: review and metaanalysis. International journal of cancer 2007, 121(8):1813-1820.

33. Hobbs CG, Sterne JA, Bailey M, Heyderman RS, Birchall MA, Thomas SJ: Human papillomavirus and head and neck cancer: a systematic review and meta-analysis. Clin Otolaryngol 2006, 31(4):259-266.

34. Li Y, Nichols MA, Shay JW, Xiong Y: Transcriptional repression of the Dtype cyclin-dependent kinase inhibitor $\mathrm{p} 16$ by the retinoblastoma susceptibility gene product pRb. Cancer research 1994, 54(23):6078-6082.

35. Klussmann JP, Gultekin E, Weissenborn SJ, Wieland U, Dries V, Dienes HP Eckel HE, Pfister HJ, Fuchs PG: Expression of p16 protein identifies a distinct entity of tonsillar carcinomas associated with human papillomavirus. The American journal of pathology 2003, 162(3):747-753.

36. Li W, Thompson CH, Cossart YE, O'Brien CJ, McNeil EB, Scolyer RA, Rose BR: The expression of key cell cycle markers and presence of human papillomavirus in squamous cell carcinoma of the tonsil. Head \& neck 2004, 26(1):1-9.

37. Rischin DYR, Fisher R, Fox S, Le Q, Peters L, Choi J, O'Sullivan B, Giralt J, McArthur G: Prognostic significance of HPV and p16 status in patients with oropharyngeal cancer treated on a large international phase III trial. J Clin Oncol 2009, 27:15s. 
38. Campisi G, Giovannelli L: Controversies surrounding Human Papilloma Virus infection, head \& neck vs oral cancer, implications for prophylaxis and treatment. Head \& neck oncology 2009, 1(1):8.

39. Lassen P, Eriksen JG, Hamilton-Dutoit S, Tramm T, Alsner J, Overgaard J: Effect of HPV-Associated p16INK4A Expression on Response to Radiotherapy and Survival in Squamous Cell Carcinoma of the Head and Neck. J Clin Oncol 2009, 27(12):1992-8.

40. Kumar B, Cordell KG, Lee JS, Prince ME, Tran HH, Wolf GT, Urba SG, Worden FP, Chepeha DB, Teknos TN, et al:: Response to therapy and outcomes in oropharyngeal cancer are associated with biomarkers including human papillomavirus, epidermal growth factor receptor, gender, and smoking. International journal of radiation oncology, biology, physics 2007, 69(2 Suppl):S109-111.

41. Worden FP, Kumar B, Lee JS, Wolf GT, Cordell KG, Taylor JM, Urba SG, Eisbruch A, Teknos TN, Chepeha DB, et al: Chemoselection as a strategy for organ preservation in advanced oropharynx cancer: response and survival positively associated with HPV16 copy number. $J$ Clin Oncol 2008, 26(19):3138-3146.

42. Cohen MA, Basha SR, Reichenbach DK, Robertson E, Sewell DA: Increased viral load correlates with improved survival in HPV-16-associated tonsil carcinoma patients. Acta oto-laryngologica 2008, 128(5):583-589.

43. Worden HJ FP, Lee J, Eisbruch A, Wolf GT, Prince M, Moyer J, Teknos T, Chepeha DB, Bradford CR, Carey T: Association of tobacco (T) use with risk of distant metastases (DM), tumor recurrence, and death in patients (pts) with HPV-positive (+) squamous cell cancer of the oropharynx (SCCOP). J Clin Oncol 2009, 27:15s.

44. Tran N, Rose BR, O'Brien CJ: Role of human papillomavirus in the etiology of head and neck cancer. Head \& neck 2007, 29(1):64-70

45. Quadrivalent vaccine against human papillomavirus to prevent highgrade cervical lesions. The New England journal of medicine 2007, 356(19):1915-1927.

46. Paavonen J, Jenkins D, Bosch FX, Naud P, Salmeron J, Wheeler CM, Chow SN, Apter DL, Kitchener HC, Castellsague X, et al: Efficacy of a prophylactic adjuvanted bivalent $\mathrm{L} 1$ virus-like-particle vaccine against infection with human papillomavirus types 16 and 18 in young women: an interim analysis of a phase III double-blind, randomised controlled trial. Lancet 2007, 369(9580):2161-2170.

47. Chang Y, Brewer NT, Rinas AC, Schmitt K, Smith JS: Evaluating the impact of human papillomavirus vaccines. Vaccine 2009, 27(32):4355-4362.

48. Kim JJ, Goldie SJ: Cost effectiveness analysis of including boys in a human papillomavirus vaccination programme in the United States. BMJ (Clinical research ed) 2009, 339:b3884.

49. Kim JJ, Ortendahl J, Goldie SJ: Cost-effectiveness of human papillomavirus vaccination and cervical cancer screening in women older than 30 years in the United States. Annals of internal medicine 2009, 151(8):538-545.

doi: $10.1186 / 1758-3284-2-15$

Cite this article as: Dayyani et al., Meta-analysis of the impact of human papillomavirus (HPV) on cancer risk and overall survival in head and neck squamous cell carcinomas (HNSCC) Head \& Neck Oncology 2010, 2:15

\section{Submit your next manuscript to BioMed Centra} and take full advantage of:

- Convenient online submission

- Thorough peer review

- No space constraints or color figure charges

- Immediate publication on acceptance

- Inclusion in PubMed, CAS, Scopus and Google Scholar

- Research which is freely available for redistribution

Submit your manuscript at www.biomedcentral.com/submit
C Biomed Central 